\title{
Trichomoniasis in pregnant women in South-East Iran: Diagnosis, frequency and factors affecting
}

\author{
Güneydoğu İran'daki hamile kadınlarda Trichomoniasis: Tanı, sıklık ve \\ etkileyen faktörler
}

\begin{abstract}
Alireza SALIMi KHORASHAD ${ }^{1,2}$ (ID), Vahid RAisSi3,4 (ID), Anita Saleh MOHAMMADZADE ${ }^{5}$ (ID), Soudabeh ETEMADi1,2 (ID), Omid RAIESiं3,6 (ID), Maryam Mansouri NiA ${ }^{1}$ (ID), Sadigheh Nouri DALiR ${ }^{1}$ (ID)
\end{abstract}

\section{ABSTRACT}

Objective: Trichomonas vaginalis is considered to be the most prevalent cause of non-viral sexually transmitted infections globally and is a major health issue in developing countries. Since this flagellate protozoan parasite is associated with vaginitis, urethritis, cervicitis, and also pregnancy is one of the factors affecting trichomoniasis in women. Our aim is to identify the prevalence of trichomoniasis and the associated risk factors in pregnant women in the age group of 17-40 in the city of Zahedan (Southeast of Iran).

Methods: A cross-sectional study was conducted on 514 pregnant women who had referred to a midwifery clinic in Zahedan. Direct microscopic examination and Dorset egg medium culture were used to detect $T$. vaginalis in pregnant women. The demographic and personal records, along with the associated risk factors were collected using a questionnaire and then analyzed using the Frequency to calculate the age average, chi-square test, independent t-test with SPSS software version 20.

Results: The results showed that in 514 pregnant women, by the direct method, both the direct and

\section{ÖZET}

Amaç: Trichomonas vaginalis, küresel olarak viral olmayan cinsel yolla bulașan enfeksiyonların en yaygın nedeni olarak kabul edilir ve gelișmekte olan ülkelerde önemli bir sağlık sorunudur. Bu kamçılı protozoan parazit, vajinit, üretrit, servisit ile ilișkili olduğundan ve ayrıca gebelik, kadınlarda trikomoniyazı etkileyen faktörlerden biridir. Amacımız, Zahedan (İran'ın Güneydoğu) şehrinde 17-40 yaș grubundaki hamile kadınlarda trikomoniyaz prevalansını ve ilișkili risk faktörlerini belirlemektir.

Yöntem: Zahedan'da bir ebelik kliniğine bașvuran 514 gebe kadın üzerinde kesitsel bir çalıșma yapılmıștır. Direkt mikroskobik inceleme ve Dorset yumurta besiyeri kültürü, gebe kadınlarda $T$. vaginalis'i saptamak için kullanıldı. Demografik ve kișisel kayıtlar, ilișkili risk faktörleriyle birlikte bir anket kullanılarak toplandı ve daha sonra yaş ortalamasını hesaplamak için Frekans, ki-kare testi, SPSS yazılımı sürüm 20 ile bağımsız t-testi kullanılarak analiz edildi.

Bulgular: Sonuçlar 514 gebede, T. vaginalis için direkt yöntemle, hem doğrudan hem de kültür

${ }^{1}$ Zahedan University of Medical Sciences, Faculty of Medicine, Department of Medical Parasitology and Mycology, Iran ${ }^{2}$ Zahedan University of Medical Sciences, Research Institute of Cellular and Molecular Sciences in Infectious Diseases, Infectious Disease and Tropical Medicine Research Center, Iran

${ }^{3}$ Tehran University of Medical Sciences, Faculty of Public Health, Department of Medical Parasitology and Mycology, Iran ${ }^{4}$ Lorestan University of Medical Sciences, Faculty of Medicine, Department of Medical Parasitology and Mycology, Iran ${ }^{5}$ Islamic Azad University, Tehran Medical Sciences, Pharmaceutical Sciences Research Center, Iran

${ }^{6}$ Ilam University of Medical Sciences, School of Allied Medical Sciences, Department of Parasitology, Iran

İletişim / Corresponding Author : Soudabeh ETEMADi

Zahedan Uni. of Med. Sci., Res. Inst. of Cellular and Molecular Sci. in Infectious Dis., Infectious

Dis. and Tropical Med. Res. Center, Iran E-posta / E-mail : ssetemadi@gmail.com

Geliş Tarihi / Received : 21.10.2020

Kabul Tarihi / Accepted : 10.02 .2021

DOI ID : 10.5505/TurkHijyen.2021.67984

Salimi-Khorashad A, Raissi V, Mohammadzade AS, Etemadi S, Raiesi O, Nia MM, Dalir SN. Trichomoniasis in pregnant women in South-East Iran: Diagnosis, frequency and factors affecting. Turk Hij Den Biyol Derg, 2021; 78(3): 507 - 516 
culture methods and only culture method, 29(5.64\%), $24(4.67 \%)$, and $24(4.67 \%)$ were reported positive sample for $T$. vaginalis, respectively. According to this result, there were significant differences between trichomoniasis and history of STI $(\mathrm{OR}=12,6 ; 95 \% \mathrm{Cl}=3$,9$40,6)$ and previous abortion $(\mathrm{OR}=6.840, \mathrm{Cl}: 2.906$ 16.100) and vaginal discharge $(\mathrm{OR}=2.9 ; 95 \% \mathrm{Cl}=1.2-7.1)$ and antenatal care $(O R=0.2 ; 95 \% \mathrm{Cl}=0.1-0.7)$ in the studied infected pregnant women $(\mathrm{p}<0.05)$.

Conclusion: This study has raised several important points that could contribute to the research on infectious diseases of pregnancy were also discussed. This data proves that trichomoniasis during pregnancy should be considered an important health issue. Furthermore, by using parasitological diagnostic tests in pregnant women, the complications of trichomoniasis can be prevented for both the mother and the fetus.

Key Words: Trichomonas vaginalis, diagnosis, frequency, pregnant women, Zahedan, Iran yöntemleriyle ve sadece kültür yöntemiyle sırasıyla $29(\% 5,64), 24(\% 4,67)$ ve $24(\% 4,67)$ pozitif örnek rapor edildiğini gösterdi. Bu sonuçlara göre, çalıșma kapsamındaki enfekte hamile kadınlarda trikomoniyaz ile CYBE öyküsü (OR = 12,6;\%95 Cl = 3,9-40,6), önceki abortus (OR = 6.840, Cl: 2.906-16.100), vajinal akıntı (OR $=2.9 ; \% 95 \mathrm{CL}=1.2-7.1)$ ve doğum öncesi bakım (OR $=0.2 ; \% 95 \mathrm{CL}=0.1-0.7)$ arasında anlamlı farklılıklar vardı $(p<0.05)$.

Sonuç: Bu çalıșma, gebeliğin bulaşıcı hastalıkları ile ilgili araștırmaya katkı sağlayabilecek birkaç önemli noktayı gündeme getirmiștir. Bu veriler, hamilelik sırasında trikomoniyaz'ın önemli bir sağlık sorunu olarak kabul edilmesi gerektiğini kanıtlamaktadır. Ayrıca gebe kadınlarda parazitolojik tanı testleri kullanılarak hem anne hem de fetüs için trikomoniyazın komplikasyonları önlenebilir.

Anahtar Kelimeler: Trichomonas vaginalis, tanı, sıklık, hamile kadınlar, Zahedan, İran

\section{INTRODUCTION}

Trichomoniasis is a sexually transmitted disease caused by a flagellate protozoan parasite called T. vaginalis (1). Men are carriers of the disease and women are its reservoirs (1). This parasite is constantly transferred between sexual partners and thus is known as the Ping-Pong-Disease (2). This parasitic infection can lead to several conditions in women including vaginitis, cervix disorders, pelvic infections, premature rupture of membranes (PROM), low birth weight, respiratory problems and conjunctivitis in neonates, infertility, and preterm birth (3). In men, this parasite can cause inflammation in the urinary tract, cystitis, and prostatitis (3). T. vaginalis shows $\mathrm{B}$-hemolytic characteristics, which can cause iron to be released from erythrocytes of the menstrual blood upon their destruction (3). In men, the presence of zinc $(\mathrm{Zn})$ in prostate secretions has a very effective protecting role against $T$. vaginalis (4). Using condoms is an effective method of prevention for trichomoniasis, and the sperm killer chemical nonoxynol-9 has destructive effects on the parasite (4). The most common complaint among patients infected with $T$. vaginalis is the presence of white or green vaginal discharge called leukorrhea (4) .70\% of the infected patients are asymptomatic, while $10 \%$ display classic symptoms, and $20 \%$ non-classic (4).

Trichomoniasis is the most common non-viral sexually transmitted infection in the world (5). Age, sex, and poor economic and health conditions are among the most important factors contributing to the 
prevalence of the infection (5). T. vaginalis survives on a wet sponge for a few hours, and in urine for up to 24 hours. The infection can be transferred nonsexually by using other people's bathing equipment and swimming in contaminated pools. It has been reported that $T$. vaginalis can spread from an infected mother to her infant daughter (6).

This parasite is visible in urinary precipitations and vaginal discharge of women, and in the urine and prostate discharges of men. It is noteworthy to mention that searching for the parasite in the urine sample should take place within 30 minutes (7). The most widely accepted method of detection is preparing a wet mount slide ( $58 \%$ sensitivity). In this fast and inexpensive method, a swab is taken from the vaginal epithelial discharge and gently coated with a warm drop of physiological serum or $\mathrm{KOH}$ on the lamellae, and then thoroughly analyzed. More recent molecular methods are also recommended in the case of negative results from direct testing and culture $(5,8)$. Herein, this study aims to analyze the prevalence of trichomoniasis in pregnant women by using both direct microscopic examination and culture.

\section{MATERIAL and METHOD}

\section{Area study and sample collection}

This study covered the period of 2017-2019 in Zahedan city (Southeast of Iran). It was conducted on 514 pregnant women in the age range of $17-40$ (with 24-36 week and more than 36 weeks pregnancy period) who had referred to a midwifery specialist and gynecologist in Zahedan. Demographic data and data associated with possible risk factors were collected. The sample size was estimated based on previous studies (9). With a prevalence of $0.3 \%$ was considered 696 pregnant women Because the study method was randomly multi-stage and available and it was not possible to obtain this volume of sample for this reason, the study was performed on 514 pregnant women. Demographic and personal records of the patients along with the associated risk factors were collected by a questionnaire. Data collection was performed by trained midwifery experts in appropriate conditions to protect the privacy and confidential information of mothers. Furthermore, the informed consent of the participants was also obtained. The inclusion criteria for the study included a pregnancy of 24 to 36 weeks and above, and the exclusion criteria consisted of pregnancy with bloody vaginal discharge.

Direct microscopy examination and culture for medical diagnosis

514 vaginal specimens were obtained from vaginal discharges of the fornix by 2 sterilized wet swabs during clinical examinations by midwifery specialists (2 swab samples were taken from each pregnant woman). Thereafter, each specimen was separately inserted in a $0.5 \mathrm{~mL}$ normal saline buffer and sent to a Diagnostic Parasitology Laboratory for detection.From each sample, a smear was prepared and analyzed under a light microscope by a medical parasitologist. Also, samples were cultured on Dorset egg medium. In this section, the steps for preparing the culture medium are explained.

Egg and distilled water with a ratio of $1 / 10$ (the added water was equivalent to 0.1 of the egg's mass), streptomycin (2 drops), starch powder as the solid phase ( 0.5 grams), and Ringer's lactate or normal saline buffer as the liquid phase of the culture medium. The second swab of each sample was added to the liquid medium and incubated at $37^{\circ} \mathrm{C}$ for 3 days. The liquid culture was evaluated to detect the growth of the parasite daily, and wet smears were used to search for trophozoite of $T$. vaginalis (10). In case the parasite was detected in direct examinations but the culture results were negative, two new samples were taken for direct and culture re-examination from the patient in their follow-up visit, and if the culture resulted negative for the presence of $T$. vaginalis, the sample would be considered negative. The most acceptable method of diagnosing $T$. vaginalis is to 
prepare a wet smear with direct microscopic and search for a parasite in the culture medium, which is up to $90 \%$ reliable $(5,8)$.

Statistics analysis

After conducting experiments and obtaining verbal questionnaires from each participant, the data were analyzed using Chi-square tests) linear-by-linear association) and for result test direct microscopy examination and culture $T$. vaginalis based different Age groups was calculated using Independent t-test and for quantitative data (mean age range) were used to describe the frequency (SPSS software version 20). In order to calculate ( $95 \%$ confidence interval) in age and education levels, groupings were changed and divided into two distinct groups (11).

This study was approved by the Zahedan University of Medical Sciences Ethics Committee (Date: 12.07.2016 and Number: IR.ZAUMS.REC.1395.285.

\section{RESULTS}

The participants of this study consisted of pregnant women in the age range of 15-42, Most of the patients were between 17 to 25 years old and the mean age of pregnant women was $25.49 \pm 6.04$ years (Figure 1).

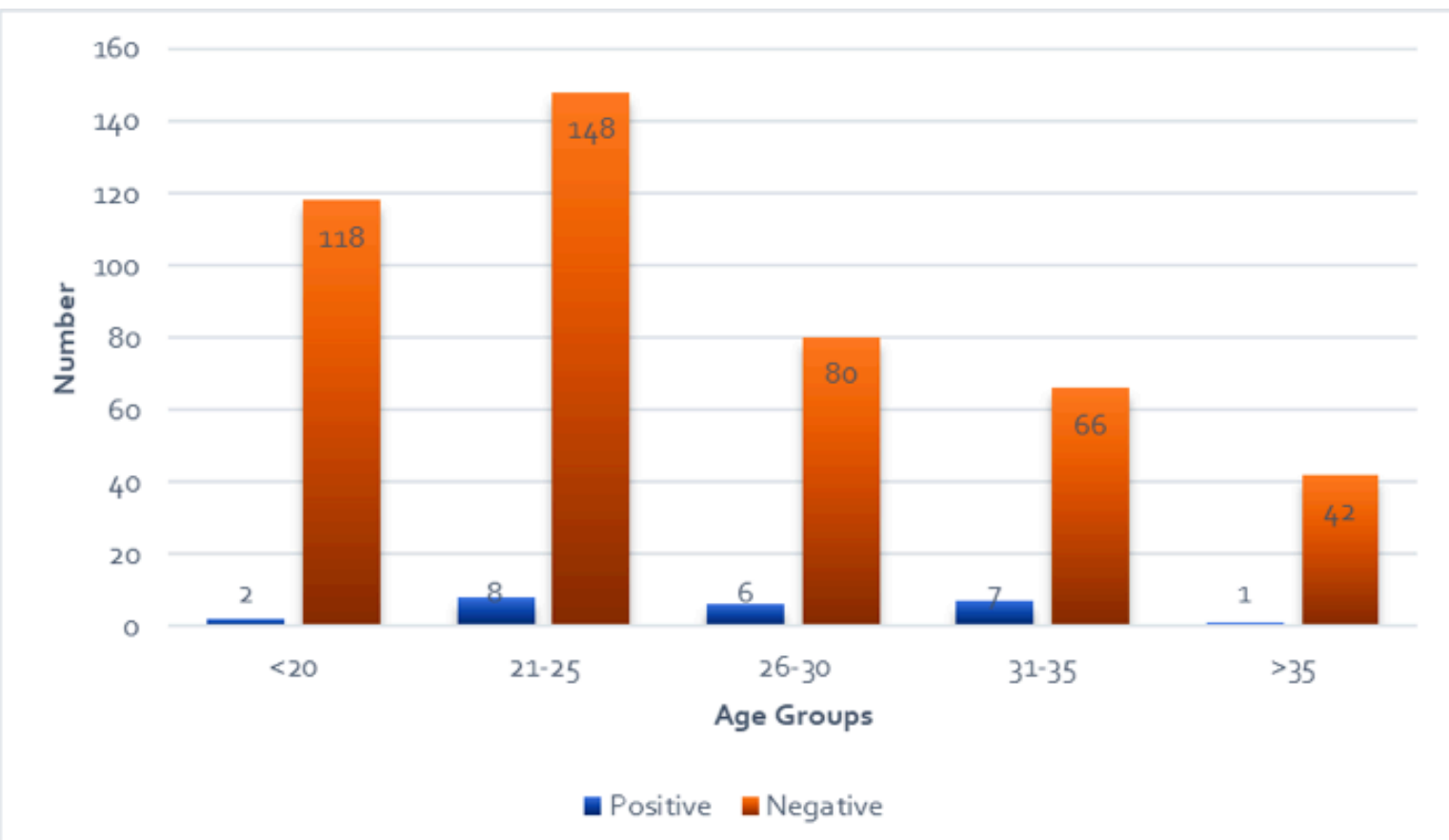

Figure 1. The results of direct microscopy examination and culture tests for $T$. vaginalis based on different age groups in pregnant women $(P$ value $=0.20)$.

Table 1 shows the prevalence of trichomoniasis in terms of demographics, behaviors and clinical characteristics. $74.5 \%$ of the studied women were urban residents and $25.5 \%$ rural. $16 \%$ of these women were illiterate, while the remaining $84 \%$ had different education levels. Inaddition, most of them were housewives (88.7\%), while only $11.3 \%$ were employed. The results showed that in 514 pregnant women, by the direct method, both the direct and culture methods and only culture method, 29(5.64\%), 
$24(4.67 \%)$, and $24(4.67 \%)$ were reported positive sample for $T$. vaginalis, respectively. Only 5 positive samples by direct method, were negative by culture method. The most important reasons for the negative culture of positive samples were the destruction of the parasites in samples, lack of growth of all parasites in culture medium and insufficient number of it for culture. Therefore, there was Medium or balanced agreement (90.56\%) between the results of direct microscopic examination and culture test (kappa index was 0.42).
In table 1 and figure 2 The relationship between trichomoniasis and demographics, behaviors and clinical characteristics in pregnant women were reported. According to this result, there were significant differences between trichomoniasis and history of STI (OR=12.6; $95 \% \mathrm{Cl}=3.9-40.6)$ and previous abortion (OR=6.8; $95 \% \mathrm{Cl}=2.9-16.1)$ and Vaginal discharge $(\mathrm{OR}=2.9 ; 95 \% \mathrm{Cl}=1.2-7.1)$ and Antenatal care $(\mathrm{OR}=0.2 ; 95 \% \mathrm{Cl}=0.1-0.7)$ in the studied infected pregnant women $(\mathrm{p}<0.05)$.

Table 1. Ihe relationship between trichomoniasis and demographics, behaviors and clinical characteristics in pregnant women of Zahedan (Southeast of Iran)

\begin{tabular}{|c|c|c|c|c|}
\hline Characteristics & Total cases N (\%) & Cases with trichomonas N (\%) & OR $(95 \% \mathrm{Cl})$ & $P$ value \\
\hline \multicolumn{5}{|l|}{ Residential Place } \\
\hline $\begin{array}{l}\text { Urban } \\
\text { Rural }\end{array}$ & $\begin{array}{l}383(74.6 \%) \\
131(25.4 \%)\end{array}$ & $\begin{array}{l}17(4.4 \%) \\
7(5.3 \%) \\
\end{array}$ & $0.82(0.33-2.03)$ & 0.672 \\
\hline \multicolumn{5}{|l|}{ Education } \\
\hline $\begin{array}{l}\text { Under Diploma } \\
\text { Upper Diploma }\end{array}$ & $\begin{array}{l}383(74.5 \%) \\
131(25.5 \%)\end{array}$ & $\begin{array}{c}16(9.8 \%) \\
8(6.5 \%)\end{array}$ & $0.67(0.28-1.60)$ & 0.367 \\
\hline \multicolumn{5}{|l|}{ Occupation } \\
\hline $\begin{array}{l}\text { Housewife } \\
\text { Employed }\end{array}$ & $\begin{array}{c}456(88.8 \%) \\
58(11.2 \%)\end{array}$ & $\begin{array}{c}22(4.9 \%) \\
2(3.5 \%)\end{array}$ & $1.41(0.32-6.19)$ & 0.640 \\
\hline \multicolumn{5}{|l|}{ Illicit drug abuse } \\
\hline $\begin{array}{l}\text { Yes } \\
\text { No }\end{array}$ & $\begin{array}{c}11(2.1 \%) \\
503(97.9 \%)\end{array}$ & $\begin{array}{c}0(0.0 \%) \\
24(4.8 \%)\end{array}$ & $1.02(1.00-1.03)$ & 0.459 \\
\hline \multicolumn{5}{|l|}{ Previous STIs } \\
\hline $\begin{array}{l}\text { Yes } \\
\text { No }\end{array}$ & $\begin{array}{c}15(2.9 \%) \\
499(97.1 \%)\end{array}$ & $\begin{array}{l}5(33.3 \%) \\
19(3.8 \%)\end{array}$ & $12.63(3.93-40.59)$ & $<0.001$ \\
\hline \multicolumn{5}{|l|}{ Previous abortion } \\
\hline $\begin{array}{l}\text { Yes } \\
\text { No }\end{array}$ & $\begin{array}{c}111(21.6 \%) \\
403(78.4)\end{array}$ & $\begin{array}{c}15(13.5 \%) \\
9(2.2 \%)\end{array}$ & $6.84(2.90-16.10)$ & $<0.001$ \\
\hline \multicolumn{5}{|l|}{ Vaginal discharge } \\
\hline $\begin{array}{l}\text { Yes } \\
\text { No }\end{array}$ & $\begin{array}{c}79(15.3 \%) \\
435(84.7 \%)\end{array}$ & $\begin{array}{l}8(10.1 \%) \\
16(3.7 \%)\end{array}$ & $2.95(1.21-7.15)$ & 0.013 \\
\hline \multicolumn{5}{|l|}{ Antenatal care } \\
\hline $\begin{array}{l}\text { Yes } \\
\text { No }\end{array}$ & $\begin{array}{c}488(94.9 \%) \\
26(5.1 \%)\end{array}$ & $\begin{array}{l}20(4.1 \%) \\
4(15.4 \%)\end{array}$ & $0.23(0.1-0.74)$ & 0.008 \\
\hline \multicolumn{5}{|l|}{ Gestational age } \\
\hline $\begin{array}{c}24-36 \text { week } \\
\text { More than } 36 \text { weeks }\end{array}$ & $\begin{array}{l}82(15.9 \%) \\
432(48.1 \%)\end{array}$ & $\begin{array}{c}6(7.3 \%) \\
18(4.2 \%)\end{array}$ & $1.81(0.69-4.72)$ & 0.216 \\
\hline
\end{tabular}




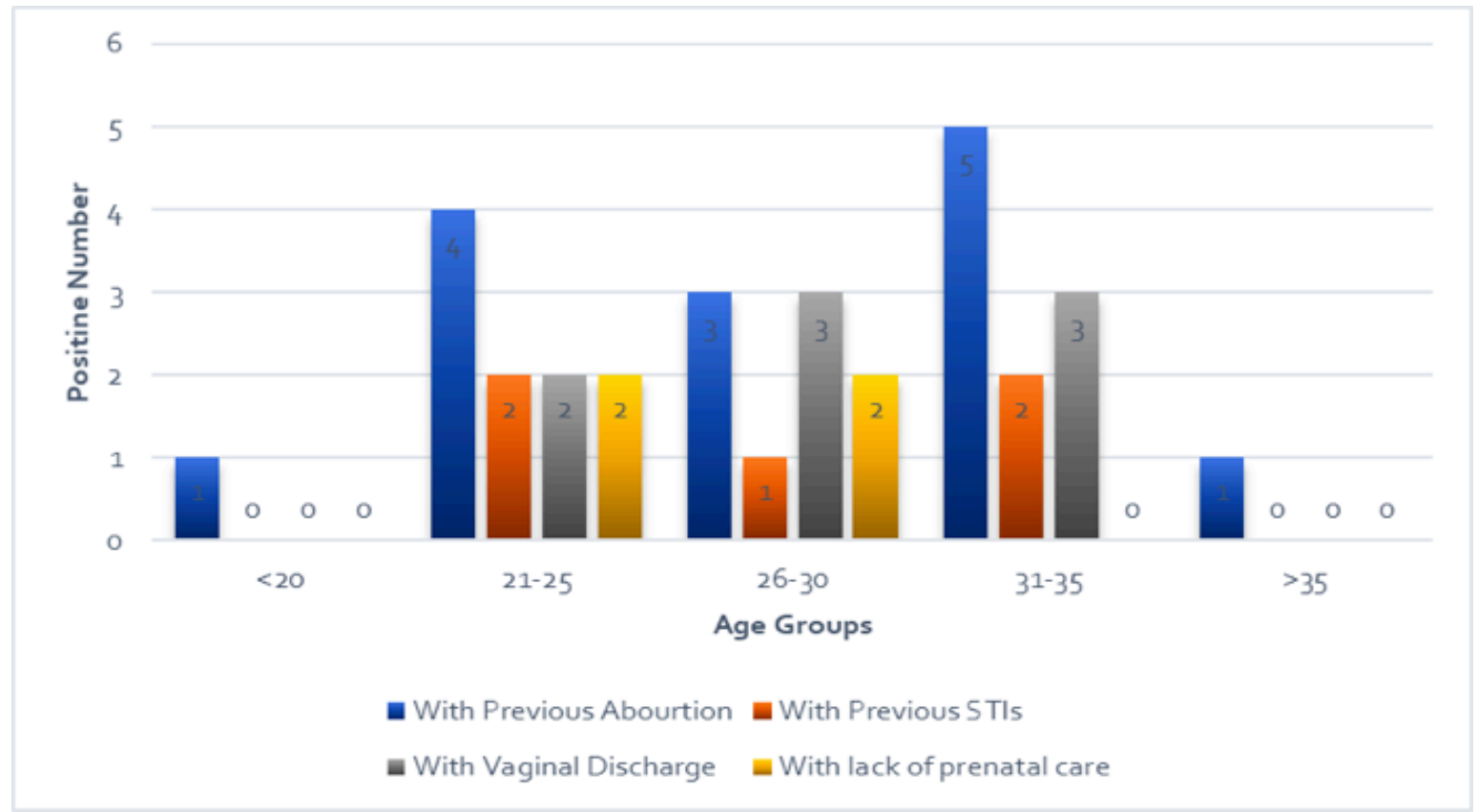

Figure 2. Number of positive individuals by various factors and Age groups

\section{DISCUSSION and CONCLUSION}

This study set out to diagnosis, frequency and factors affecting on Trichomoniasis in pregnant women in South-East Iran. To investigate this, direct microscopic examination and Dorset egg medium culture were used to detect $T$. vaginalis in pregnant women. In the following, the demographic and personal records, along with the associated risk factors were collected using a questionnaire and then analyzed using the frequency to calculate the age average, Chi-square test, Independent t-test and SPSS software version 20. Analysis of data revealed that in pregnant women there were associated elements with trichomoniasis to be a history of STI and previous abortion. The current findings add substantially to our understanding of relationship and effect of trichomoniasis in pregnancy from epidemiological and clinical aspects on pregnant mothers.
The studies at hand show that the prevalence of trichomoniasis in pregnant women in different continents of the world is as follows: ranged from 3.9-24.6\% in Latin America and Southern Africa (12), less than $10 \%$ in Europe (13) and between 0.4 $\%$ to $45 \%$, espacially Middle East, in Asia (14-16). The results of the current paper demonstrated that $4.6 \%$ of pregnant women in Zahedan were infected with $T$. vaginalis. The infection rates reported in this study were lower in comparison with the several studies in Nigeria and Brazil $(17,18)$. Furthermore, in this study, the history of vaginal discharge, STI and previous abortions were the associated variables with increasing trichomoniasis in the studied pregnant women, however, there was no significant correlation between $T$. vaginalis infection and other variables. In addition, there was no significant correlation between trichomoniasis in pregnant women and the independent variable of age groups. Based on the fact that the prevalence of trichomoniasis in women in 
the age groups of $16-35$, according to the conducted research, is due to increased sexual activities, only $4.02 \%$ of the studied pregnant women who were below 30 were infected with $T$. vaginalis. These results matched the study carried out on pregnant women by Uneke et al in 2010 (19), which reported the highest prevalence of trichomoniasis to be in the age group of 26-30, while the study of Alo et al in 2012 was reported $36 \%$ of the prevalence in the age group of $31-35(19,20)$.

The infection rates of urban pregnant women were 2.4 times higher than those living in rural places. Considering the factors affecting the prevalence of trichomoniasis, including economic, cultural, and health conditions, further investigation is needed on the Residential Place variable with the aforementioned associated variables. The prevalence of trichomoniasis infection in this study was twice as high in pregnant women without a high school diploma than those with higher education levels, suggesting that education and awareness of women regarding personal and sexual health and STD prevention methods can reduce their prevalence and complications. No significant correlation was found between occupation and trichomoniasis infection. Uncertainty in the results of this study could be due to the low levels of employed participants.

In study conducted by Alo et al in 2012 showed that $10 \%$ of the pregnant women in their second trimester and $5.5 \%$ in their third trimester were infected with trichomoniasis, the infection was not observed in the first trimester of pregnancy (20). In the current study, women in their third trimester of pregnancy were available and tested. Since untreated trichomoniasis infections last for at least three months, and during this period can lead to reproductive health consequences, timely screening can prevent negative consequences of pregnancy (21-23). Therefore, screening tests for T. vaginalis are recommended for women in their second or early third trimester of pregnancy. In the present study,
$33.3 \%$ of pregnant women had a history of previous STIs, and a higher prevalence of trichomoniasis in women with STIs was reported in some regions (24). Furthermore, $13.5 \%$ of the infected women had a history of a previous abortion (24). This significant correlation proves that these elements should be considered as risk factors to assess the prevalence more accurately and screen the patients with greater sensitivity in women with such histories. According to some comparative studies in pregnant women with and without trichomoniasis, infected women show a $30 \%$ risk of low weight birth (25). Also, the role of trichomoniasis in causing dangerous complications during pregnancy for mothers and fetus has been proven in various studies, for example: Abortion, Uterine rupture, etc (28-31). The current data show that discussing routine screening for trichomoniasis during pregnancy and before labor can prevent the associated complications.

As for the survey on examine the subject in more detail, there were two main limitations. First, although maximum attempt was made to use a questionnaire with items that were chear and relevant, further access to clinical information for pregnant women was not possible. Second, many pregnant mothers do not participate in the study due to lack of sufficient knowledge about the subject. There is clearly much room for further research in this respect. For example, simultaneous effect of sexually transmitted infections such as Chlamydia trachomatis and $T$. vaginalis on the severity of clinical symptoms in pregnant women and their fetuses.

In conclusion, this study has raised several important points that could contribute to the research on infectious diseases of pregnancy were also discussed. In this paper, we presented a study in which we investigated the prevalence of trichomoniasis in pregnant women (514 specimens of vaginal discharges). Pregnant women with trichomoniasis were studied based on terms of clinical symptoms (a history of vaginal discharge, 
STI and previous abortion). Our finding suggests that 24/514 (4.6\%) were infected with $T$. vaginalis by two methodes and A statistically significant difference between a history of STI and a previous miscarriage and prevalence of diseases in pregnant women was found. So, this data proves that trichomoniasis during pregnancy should be considered an important health issue. Furthermore, by using a parasitological screening test in pregnancy, the complications of trichomoniasis can be prevented for both the mother and the fetus.

\section{ACKNOWLEDGMENTS}

The authors express their appreciation and gratitude to all those who have directly or indirectly contributed to this project.

\section{ETHICS COMITTEE APPROVAL}

* The study was approved by the Zahedan University of Medical Sciences Ethics Committee (Date: : 12.07.2016 and Number: IR.ZAUMS.REC.1395.285).

\section{CONFLICT OF INTEREST}

The authors declare no conflict of interest. 


\section{REFERENCES}

1. Mirzaei F, Raissi V, Teimouri AT, Mousavi P, Mohaghegh MA, Manshadi MD, Zare F, Esboei BR. Anti-Trichomonas Vaginalis Activity of Ethanolic Extracts of Medicago Sativa and Satureja Hortensis, In Vitro Study. IJML , 2019 ; 6(3):166-171.

2. Secor WE, Meites E, Starr MC, Workowski KA. Neglected parasitic infections in the United States: trichomoniasis. AJTMH, 2014;90(5):800-4.

3. Schwebke JR, Burgess D. Trichomoniasis. CMR, 2004 ;17(4):794-803.

4. Fichorova RN. Impact of T. vaginalis infection on innate immune responses and reproductive outcome. J Reprod Immunol,2009 ;83(1-2):185-9.

5. Nourian A, Shabani N, Fazaeli A, Mousavinasab SN. Prevalence of Trichomonas vaginalis in pregnant women in Zanjan, Northwest of Iran. Jundishapur J Microbiol, 2013;6(8):10.

6. Valadkhani Z, Assmar M, Esfandiari B, Amirkhani A, Hassan N, Lotfi ML, Ghobadi-rad S. Trichomoniasis in asymptomatic patients. Iran J Public Health, 2008:113-7.

7. Patel EU, Gaydos CA, Packman ZR, Quinn TC, Tobian AA. Prevalence and correlates of Trichomonas vaginalis infection among men and women in the United States. Clin Infect Dis, 2018;67(2):211-7.

8. Schwebke JR, Hobbs MM, Taylor SN, Sena AC, Catania MG, Weinbaum BS, Johnson AD, Getman DK, Gaydos CA. Molecular testing for Trichomonas vaginalis in women: results from a prospective US clinical trial. JCM,2011;49(12):4106-11.

9. Matini M, Rezaei H, Fallah M, Maghsood AH, Saidijam M, Shamsi-ehsan T. Genotyping, drug susceptibility and prevalence survey of Trichomonas vaginalis among women attending gynecology clinics in Hamadan, western Iran, in 2014-2015. Iran J Parasitol, 2017;12(1):29-37.

10. Radonjic IV, Dzamic AM, Mitrovic SM, Arsenijevic VS, Popadic DM, Zec IF. Diagnosis of Trichomonas vaginalis infection: the sensitivities and specificities of microscopy, culture and PCR assay. Eur J Obstet. Gynecol Reprod Biol, 2006;126(1):116-20.
11. Miranda AE, Pinto VM, Gaydos CA. Trichomonas vaginalis infection among young pregnant women in Brazil. Braz J Infect Dis, 2014;18(6):669-71.

12. Menezes CB, Frasson AP, Tasca T. Trichomoniasisare we giving the deserved attention to the most common non-viral sexually transmitted disease worldwide?. MIC, 2016 Sep 5;3(9):404.

13. Bolumburu $C$, Zamora $V$, Muñoz-Algarra $M$, Portero-Azorín F, Escario JA, Ibáñez-Escribano A. Trichomoniasis in a tertiary hospital of Madrid, Spain (2013-2017): prevalence and pregnancy rate, coinfections, metronidazole resistance, and endosymbiosis. Parasitol Res, 2020 ; 119:1915-1923.

14. Arbabi $M$, Delavari $M$, Fakhrieh-Kashan $Z$, Hooshyar H. Review of T. vaginalis in Iran, based on epidemiological situation. J Reprod Infertil, 2018;19(2):82.

15. AL-Muathen DM, Sachit HG. Prevalence Trichomoniasis and Candidiasis For Symptomatic Pregnant and Non Pregnant Women in Iraq.AJPS, 2018;16(2):21-6.

16. Yenidunya S, Hatlas $H$, Bayrak R. To determine of the prevalence of Bacterial Vaginosis, Candida $\mathrm{sp}$, mixed infections (Bacterial Vaginosis+ Candida $\mathrm{sp})$, Trichomonas Vaginalis, Actinomyces $\mathrm{sp}$ in Turkish women from Ankara, Turkey. Ginekol Pol, 2012;83(10).

17. de Lemos PA, Garcia-Zapata MT. The prevalence of Trichomonas vaginalis in HIV-positive and negative patients in referral hospitals in Goiania, Goias, Brazil. Int J Trop Med, 2010;5(2):24-7.

18. Donbraye E, Donbraye-Emmanuel OO, Okonko IO, Okedeji IO, Alli JA, Nwanze JC. Detection and prevalence of Trichomonas vaginalis among pregnant women in Ibadan, Southwestern Nigeria. World Appl Sci J, 2010;11(12):1512-7.

19. Uneke CJ, Alo MN, Ogbu O, Ugwuoru DC. Trichomonas vaginalis infection in human immunodeficiency virus-seropositive Nigerian women: The public health significance. Online J, 2007;6(2). 
20. Alo MN, Anyim C, Onyebuchi AK, Okonkwo EC. Prevalence of asymptomatic co-infection of candidiasis and vaginal trichomoniasis among pregnant women in Abakaliki, South-Eastern Nigeria. J Nat Sci Res, 2012;2(7):87-91.

21. Moodley P, Wilkinson D, Connolly C, Moodley J, Sturm AW. Trichomonas vaginalis is associated with pelvic inflammatory disease in women infected with human immunodeficiency virus. Clin Infect Dis, 2002;34(4):519-22.

22. Mahdi NK, Gany ZH, Sharief M. Risk factors for vaginal trichomoniasis among women in Basra, Iraq. EMHJ, 2001;7 (6), 918-924.

23. Auta, I., B. Ibrahim and D. Henry. "prevalence of $\mathrm{T}$. vaginalis among pregnant women attending antenatal clinic in two health facilities within kaduna metropolis, kaduna, nigeria. Sci World J, 2020;15(1):97-101.

24. Wayal S, Aicken CR, Griffiths C, Blomquist PB, Hughes $\mathrm{G}$, Mercer $\mathrm{CH}$. Understanding the burden of bacterial sexually transmitted infections and T. vaginalis among black Caribbeans in the United Kingdom: Findings from a systematic review. PLOS ONE, 2018;13(12):e0208315.

25. Van Der Pol B, Williams JA, Orr DP, Batteiger BE and Fortenberry JD . Prevalence, incidence, natural history, and response to treatment of $\mathrm{T}$. vaginalis infection among adolescent women. J Infect.Dis, 2005;192(12): 2039-2044.
26. Kim TG, Young MR, Goggins ER, Williams RE, HogenEsch E, Workowski KA, Jamieson DJ, Haddad LB. T. vaginalis in Pregnancy: Patterns and Predictors of Testing, Infection, and Treatment. Obstet Gynecol, 2020;135(5):1136-44.

27. Teasdale CA, Abrams EJ, Chiasson MA, Justman $\mathrm{J}$, Blanchard $\mathrm{K}$, Jones HE. Incidence of sexually transmitted infections during pregnancy, PLOS ONE, 2018;13(5):e0197696.

28. Gatti FA, Ceolan E, Greco FS, Santos PC, Klafke GB, de Oliveira GR, Von Groll A, de Martinez AM, Gonçalves CV, Scaini CJ. The prevalence of trichomoniasis and associated factors among women treated at a university hospital in southern Brazil. PLOS ONE, 2017;12(3):e0173604.

29. Menéndez C, Castellsagué X, Renom M, Sacarlal J, Quintó L, Lloveras B, Klaustermeier J, Kornegay JR, Sigauque B, Bosch FX, Alonso PL. Prevalence and risk factors of sexually transmitted infections and cervical neoplasia in women from a rural area of southern Mozambique. Infect Dis Obstet Gynecol, 2010; (1155):1-9.

30. Tann CJ, Mpairwe H, Morison L, Nassimu K, Hughes P, Omara M, Mabey D, Muwanga M, Grosskurth $H$, Elliott $A M$. Lack of effectiveness of syndromic management in targeting vaginal infections in pregnancy in Entebbe, Uganda. Sex Transm Infect, 2006;82(4):285-9.

31. Eisinger RW, Erbelding E, Fauci AS. Refocusing research on sexually transmitted infections. J Infect Dis, 2020;222(9):1432-4. 